\title{
Неокорпоративізм як механізм взаємоАії між державою та групами інтересів
}

\author{
C.A. KBITKA \\ Аніпропетровський регіональний інститут Аержавного управління \\ Національної акалемії державного управління при Презилентові України, \\ м. Аніпропетровськ, Україна, E-mail: skvitka@i.ua
}

\section{Авторське резюме}

У статті розглядається неокорпоративізм як механізм забезпечення стабільних та продуктивних взаємовідносин держави і суспільства. Ключову роль у системі цих взаємовідносин відіграють групи інтересів, які репрезентують головних акторів цього процесу - бізнес та громадянське суспільство. Діяльність таких груп інтересів, що шукають шляхи впливу на процес прийняття рішень і на переорієнтацію владних структур відповідно до інтересів своїх членів, є фактором повсякденного політичного життя України. Тому тема неокорпоративізму все більше привертає увагу вчених, постійно зростає кількість теоретичних і дослідницьких робіт присвячених розгляду досвіду неокорпоративізму на Заході і аналізу взаємодії груп інтересів і держави в умовах переходу до неодемократії. Автор робить висновок, що українській державі слід створити правову нішу для легітимного функціонування підприємницьких спілок та асоціацій, що зможуть легітимно впливати на політику державних органів і визначити, з одного боку, допустимий оптимум коридору економічної свободи, а з іншого - максимально вмонтувати механізми ринкового саморегулювання в структури реалізації функцій держави.

Ключові слова: неокорпоративізм, групи інтересів, бізнес асоціації, громадянське суспільство, економічна свобода, глобалізація, плюралізм.

\section{Neo-corporatism as a mechanism for interaction between the government and interest groups}

\author{
S.A. KVITKA \\ Dnepropetrovsk regional institute of public administration, the National \\ academy of public administration, office of the President of Ukraine, \\ Dnepropetrovsk, Ukraine, E-mail: skvitka@i.ua
}

\section{Abstract}

The article considers the neo-corporatism as a mechanism to ensure stable and productive relations between the state and society. A key role in these relationships play interest groups representing the main actors of this process - business and civil society. The activities of interest groups seeking ways to influence decision-making and reorientation authorities in accordance with the interests of its members is a factor of everyday political life in Ukraine. Therefore, subject neokrporatyvizmu increasingly attracted the attention of scientists, constantly growing number of theoretical and research devoted to the consideration of the experience in the West neo-corporatism and analyze the interaction of interest groups and the state in the transition to neo-democracy. The author concludes that the Ukrainian state should create a legal niche for legitimate functioning of business associations and associations that can legitimately influence on politics and government bodies to determine, on the one hand, the allowable corridor optimum economic freedom, and the other - the maximum build market self-regulation mechanisms in structure of state functions.

Keywords: neo-corporatism, interest groups, business associations, civil society, economic freedom, globalization, pluralism.

(C) С.А. Квітка, 2014 
Постановка проблеми. У сучасному світі відносини держави і суспільства стають все більш складними i взаємозалежними. Вчені і політики різних країн шукають методи подолання об'єктивних викликів державному управлінню до числа яких належать: процеси глобалізації i пов'язана 3 ними зміна ролі національних держав, економічний i coціальний дисбаланс у суспільстві, проблеми забезпечення екологічної та військової безпеки. Нові виклики, пов'язані, в першу чергу, 3 ускладненням політичної системи, створюють постійно зростаючий попит на керованість. Як показуе досвід розвинених країн, забезпечити керованість у сучасних суспільствах тільки зусиллями держави вже неможливо [8]. У цьому зв'язку переосмислення концепції неокорпоративізму може стати ключем до подолання проблем державного управління в Україні i, як наслідок, сприятиме зміцненню їі економічної та політичної систем.

Постійний інтерес учених до теми неокорпоративізму викликаний також низкою актуальних факторів до числа яких можна віднести успішне існування і розвиток системи неокорпоративізму в країнах Західної Європи, формування неокорпоративних принципів організації в органах управління Європейського Союзу [10].

Актуальність вивчення проблеми неокорпоративізму затребувана i все більш зростаючою в Україні роллю різного роду груп інтересів, які багато в чому визначають характер взаємовідносин між суспільством i державою та особливості трансформації системи влади. Для України, політична система якої ще далеко не усталилася, дослідження зв'язку «суспільство - держава» набуває особливо важливого значення для виявлення найбільш істотних тенденцій і проблем подальшого розвитку країни. При визначенні характеристик існуючого політичного режиму в Україні можна констатувати його явно олігархічний характер, що висуває на порядок денний низку гострих проблем, вирішення яких необхідне для розвитку країни, а не стагнації на рівні перехідного періоду, який триває вже понад 20 років. Зокрема, це високий рівень соціальної диференціації між «бідними» i «багатими», диспропорції в системі політичного представництва організованих груп інтересів, відсутність усталених інститутів їх взаємодії 3 державою, відсутність чітко фіксованих у законодавстві форм і методів лобістської діяльності i, нарешті, сама етика взаємовідносин між владою та бізнесом [11]. Від вирішення цих проблем, що стоять перед державою, багато в чому залежить те, яким шляхом піде Україна i, в тому числі, можливості та перспективи їі інтеграції з Європейським Союзом.

Значущість вивчення неокорпоративізму пояснюється також системними суспільно-політичними змінами, що відбуваються в Україні. Основними суб'єктами цих змін виступають, поряд 3 державою, громадянське суспільство і бізнес - ключові актори політики неокорпоративізму. Діяльність груп інтересів, що шукають шляхи впливу на процес прийняття рішень i на переорієнтацію владних структур відповідно до інтересів своїх членів, є фактором повсякденного політичного життя України. В той же час нові спроби здійснення певними зацікавленими групами «монополізації» громадських інтересів, а також "приватизації» ними держави і громадянського суспільства задає небезпечний непідконтрольний вектор майбутнього політично- 
го розвитку країни. В цьому зв'язку завдання впровадження неокорпоративістської моделі державного управління та створення адекватного представництва організованих груп інтересів у ході реформування політичної системи України є одним 3 найбільш актуальних.

Аналіз досліджень і публікацій. До теперішнього часу обширний концептуально-методологічний матеріал з проблем груп інтересів і неокорпоративізму в більшості своїй страждає відсутністю комплексності та системності. Багато наукових праць, що присвячені розгляду феномена «груп інтересів», часто мають описовий характер, акцентуючи увагу на конкретних організаціях, об'єднаннях або рухах. При цьому особлива увага приділяється найбільш впливовим групам, як особливим політичним акторам, що визначають і лобіюють свої інтереси в органах державної влади. Йдеться насамперед про фінансово-промислові групи, підприємницькі асоціації та бізнес-еліти [2]. Оскільки термін «неокорпоративізм» прийшов до нас із Заходу, то природно виділити зарубіжну літературу, переважно англомовну, що аналізує в теоретичному плані питання про групи інтересів і оцінює специфіку та характер їх впливу на процес прийняття рішень державними органами (Г.Лембрух, Ф.Шміттер, З.Бжезинський, Л.Шапіро, Г.Скіллінг, В.Брус, Дж.Ехолс, А.Болл, Ф.Міллард, Р.Хейг, М.Херроп та ін.).

Інша група досліджень неокорпоративізму представлена роботами вчених, які працюють на пострадянському просторі. Велика кількість таких теоретичних i дослідницьких робіт присвячена розгляду концепції неокорпоративізму на Заході i спробам iï застосування до аналізу взаємодії груп інтересів і держави в умовах переходу до неодемократій. 3 найбільш помітних авторів можна виділити таких як I.Семененко, С.Перегудов, Р.Гайнутдінов, I.Сало, О.Даніляк, Т.Джіга, В.Гончар та ін.

Мета дослідження. Аналіз концепції неокорпоративізму та можливості їі впровадження в Україні є основною метою цього дослідження. Разом з тим уявляється необхідним проаналізувати слабкі та сильні сторони неокорпоративізму, його особливості у сучасному світі.

Виклад основного матеріалу. Що ж таке неокорпоративізм, чому він виникає i які його наслідки? Сам термін безпосередньо витікає 3 поняття «корпоративізм», який свого часу означав певний ідеал суспільного ладу, при якому індивідууми беруть участь у політичному та економічному житті корпорацій, тобто професійні групи, до яких вони належать. Таким чином, термін корпоративізм був запозичений ще із середньовіччя, коли за господарською активністю доглядали професійні корпорації (цехи, гільдії і т.п.). Вони здійснювали контроль не тільки виробничої активності своїх членів, а й інших сфер їхнього життя. Вони, між іншим, брали участь у формуванні міського самоврядування в середньовічних містах. Подальша еволюція корпоративізму відбувалась у різних формах і на момент нового відкриття в середині 1970-х років цей термін ніс на собі тягар асоціацій з фашизмом та іншими формами авторитарного правління.

Сучасний варіант корпоративізму в умовах ліберальної демократії називається неокорпоративізмом, який i є предметом подальшого аналізу.

Неокорпоративізм як суспільнополітичне явище виникає на певному етапі розвитку суспільства. Його еволюція відбувалась при тісній взаємодії з ліберальною доктри- 
ною. Ця взаємодія значною мірою сприяла визріванню інструментально-технологічного підходу до корпоративізму, що визначилась через інституціоналізацію взаємозв'язків держави й громадянського суспільства. Іншими словами, корпоративізм, виступивши на початку $\mathrm{XX}$ століття ідеологічним викликом лібералізму, зміг наприкінці $\mathrm{XX}$ століття, вже у вигляді неокорпоративізму, «Ужитися» в ліберальну політичну систему, засновану на протистоянні держави й громадянського суспільства, стабілізуючи й

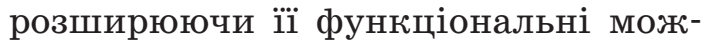
ливості [1] .

Неокорпоративізм виник як результат взаємодоповнення корпоративізму й ліберального плюралізму. Він містить у собі: систему функціонального представництва, що доповнює парламентаризм, партійно-територіальне представництво; групи представництва бізнесу й праці як головних учасників неокорпоративних угод; інститути соціального партнерства на всіх рівнях - національному, регіональному (галузевому), локальному. Неокорпоративна модель стала важливим елементом демократизації європейських країн, тому що розширювала можливості діалогу між державою й громадянським суспільством за допомогою функціонального представництва, стабілізувала соціально-економічні процеси усередині країни за допомогою інститутів соціального партнерства. У середині 1970-х років науковці з різних країн світу практично одночасно звернулися до цього поняття для опису ряду особливостей політичної дійсності розвинених демократій, які, на думку дослідників, далеко не повною мірою пояснювалися поширеною тоді моделлю, що застосовувалась для характеристики відносин між державою і сус- пільством, тобто моделлю плюралізму. У 1980-х роках більшість країн Східної Європи почали перехід від авторитаризму до різних форм демократії і актуальним стало питання про можливість реального впливу на державу громадянського суспільства та бізнесу, що почали активно розвиватись. Тоді ж розгорнулись і дискусії про некорпоративізм або його аналоги: узгодження інтересів, соціальне партнерство і т.п. Цьому сприяло і те, що в той час неокорпоративізм розглядався на Заході мало не як панацея від усіх проблем i недоліків буржуазного суспільства, що переживало тоді гостру структурну кризу [15].

До прикладів країн з усталеними неокорпоративними традиціями, соціальна тканина яких глибоко пронизана відповідними відносинами, можна віднести насамперед Австрію, Фінляндію, Норвегію та Швецію. Важливі елементи неокорпоративізму при виробленні макроекономічної політики були відзначені в Австралії, Бельгії, ФРН, Данії, Нідерландах, а також у таких неодемократіях, як Португалія і Іспанія. В 1960 - 1970-х рр. спроби (правда, безуспішні) ввести подібну практику робилися у Великобританії та Італії. В інших країнах, наприклад у Франції, Канаді та Сполучених Штатах, поширення неокорпоративізму, обмежилося окремими галузями або регіонами [6].

Неокорпоративізм визначають i як ідеологію, і як різновид політичної культури чи державного устрою, i як форму організації економіки, i навіть як особливий тип суспільства. Але найбільш продуктивним виявився підхід, у рамках якого некорпоративізм розглядається в якості одного 3 можливих механізмів, що дозволяють різним асоціаціям, створених на основі спільних інтересів, бути посе- 
редником між своїми членами (індивідами, фірмами, локальними спільнотами, групами інтересів) і різними контрагентами (в першу чергу, державними органами та органами місцевого самоврядування). Головну роль у цьому процесі відіграють міцно вкорінені асоціації 3 постійним штатом, які спеціалізуються на вираженні інтересів і прагнуть виявляти, просувати і захищати їх за допомогою впливу на публічну політику. На відміну від політичних партій - іншого важливішого посередника ці організації не виставляють своїх кандидатів на виборах і не беруть на себе пряму відповідальність за формування уряду. Коли такі асоціації (i особливо вся мережа таких асоціацій) певним чином організовані або коли вони певним чином беруть участь у процесі прийняття рішень на різних рівнях державної або місцевої влади, можна говорити про неокорпоративізм [9].

Таким чином, неокорпоративізм можна охарактеризувати i як систему діалогу між представниками апарату влади і групами, які представляють інтереси економічних секторів або соціальних верств. У неокорпоративній системі групи інтересів отримують можливість дійсної співучасті у владі і несуть спільну відповідальність за їі результати. В цьому неокорпоративізм відрізняється від плюралізму. Під останнім розуміється система представництва інтересів, в якій складові частини організовані в необмеженому числі різнорідних, добровільних, конкуруючих між собою, без ієрархічної впорядкованості структур.

На відміну від плюралізму, неокорпоративізм у своїй філософії свідомо відмовляється від проведення державної політики, заснованій на конфлікті інтересів, а тому він конструюється на підставі катего- рії консенсусу. Найбільш ранні прояви такої політики консенсусу проявилися в Швейцарії та Швеції. Під впливом світової кризи у Швейцарії було укладено «суспільний мир", основні принципи якого збереглися до теперішнього часу (в тому числі і в політичних інститутах). Аналогічно в Швеції Федерація профспілок уклала угоду зі Шведським об'єднанням роботодавців з питання ринку праці. В силу цього договору була створена Комісія у справах ринку праці, основним завданням якої було втримати державу від втручання у функціонування ринку. Поряд із цим державна політика вимагала вбудовування в систему державного управління механізмів, що дозволяють при прийнятті рішеннь враховувати інтереси значущих груп інтересів. Також проявився тиск на функціональний характер представництва певних важливих груп в процесі прийняття державних рішень. Таким чином, апарат влади зміг забезпечити собі значний суспільний контроль, наприклад у стримуванні агресивних форм протесту, ініційованих лідерами профспілок [13].

Існує кілька різних підходів до вивчення неокорпоративізму. У цій статті не йдеться про аналіз всіх цих концепцій. Відзначимо лише, що, на наш погляд, найбільш адекватною видається позиція американського вченого Ф.Шміттера. Під неокорпоративізмом він розуміє спосіб організації інтересів і взаємодії з державою, що різниться від попередніх i, насамперед, відрізняється від плюралізму. Відповідно до його концепції неокорпоративізм можна визначити як систему представлення інтересів, в якій складові частини організовані у вигляді невеликого числа окремих, примусових таких що не конкурують між сосбою, ієрархічно організованих і функціо- 
нально диференційованих структур, визнаних або легалізованих державою. Вони наділяються різного роду монополіями в сфері представництва даної категорії справ взамін за здійснення певного контролю за відборомв лідерів, вираженням вимог i підтримки держави [14].

Основне питання неокорпоративізму - що є мірою оцінки ефективності демократії? Чи то громадяни, чи то політична влада? Або ж інакше кажучи: чи відноситься якість демократії до волевиявлення громадян (уряд «з народу») або ж до інституту, який керує ними від їх імені (уряд «для народу»)?

У неокорпоративній системі уряд повинен бути «доступним», тобто трактувати вимоги громадян як найбільш важливі при прийнятті рішень загального характеру. Уряд «несе відповідальність» завдяки регулярним консультаціям та дебатам, призначення яких не може вирішуватися довільно. Такий уряд i взагалі державну владу характеризує чутливість до вимог суспільства - колективна риса демократичного правлячого класу. Зазначена чутливість влади гарантуе те, що потреби громадян будуть задоволені, а отже, і дії публічної влади будуть легітимними [10]. У певному сенсі неокорпоративізм заново створює політичний лад. Тобто він займається, перш за все, діяльністю асоціацій або окремих груп інтересів, які спеціалізуються в управлінні певною категорією інтересу. При цьму вони не можуть бути виробничими організаціями (фірми, підприємства, корпорації), не статусними організаціями, не структурами публічної влади (урядові установи, міністерства, парламенти, органи самоврядування). Зазначені об'єднання намагаються «протягти» або захистити громадські інтереси за допомогою здійснен- ня впливу, або коли вони ставлять під сумнів систему і результати політичних виборів. Таким чином, вони приводять до створення впливових інститутів, які $є$ посередником між структурами, що представляють певний інтерес, і органами публічної влади [8].

Будь-який спосіб посередництва між групами інтересу повинен враховувати два аспекти політичного процесу. Перший - визначення способу здійснення комунікації і перетворення переваг членів даної групи інтересу на вимоги по відношенню до влади та інших груп. Другий представництво, а саме: проведення моніторингу виконання вимог та визначення способу впливу, що має на меті здійснення цих вимог, або їх контроль. Сучасний неокорпоративізм в країнах, де він застосовується, демонструє послідовні якісні зміни в демократичній політиці: правління більшості, суверенність парламентів, публічні дебати тощо. Він також вводить елементи «зваженого» розрахунку і консенсусних переговорів з привілейованими меншинами, які явно зневажають освячені часом демократичні норми. Спрацьовує формула - «одна людина - один голос» i «більшість голосів виграє». Таким чином, при неокорпоративізмі акцент $з$ волюнтаристичного та індивідуального розрахунку зміщується на такий, де участь у процесі формування політики є обов'язковою для всіх членів даної категорії інтересу [10].

Неокорпоративізм організуе привілейовані інтереси за функціональною ознакою, що випливає з виробництва в капіталістичній економіці - класів, галузей i професій. При цьому, і це слід пам'ятати завжди, його успіх залежить від обмеження кількості та ідентифікації учасників, від перенесення затрат на тих, хто не притягнутий безпосередньо до 
цих дебатів (на споживачів, платників податків, молодь, жінок, іноземців, культурні меншини і т. п.) [4].

3 часів французької революції теорія демократії була ототожнена 3 ліберальною боротьбою проти обмежень, які накладалися на економічну та суспільну поведінку індивідуумів: гільдії, монополії, дозволи на заняття професією і т.п. Неокорпоративізм же змінюе не тільки природу об'єднання, але й формування політики, а також зв'язки між керівництвом груп інтересів та їх членами. Об'єднання (асоціації) не тільки інформують публічну владу про уподобання своїх членів та їх реакції, а й дають згоду членів на досягнуті в результаті переговорів угоди.

Ф.Шміттер вказує, що ефективність державного управління, що забезпечує стабільність у суспільстві у меншій мірі проявляється як функція відсутності рівноваги між суспільними вимогами і можливостями держави. Набагато більшою мірою воно проявляється як процес ідентифікації, сприяння та реалізації потенційних очікувань організацій інтересу. Порушення цього процесу призводить до нестабільності. Можна виділити два рівні такої нестабільності: 1 - громадянські протести, які перероджуються в масову непокору, страйки, заворушення і 2 - відсутність стабільного уряду (зміна урядів, падіння популярності правлячої партії, втрата фракційної дисципліни в парламенті). Третьою можливою формою нестабільності є відсутність ефективності при збоpi податків: чим менше уряд в змозі забезпечити ефективність використання податків, тим більше він стає неефективним у їх збиранні. До найбільш неефективних у цьому плані, тобто відступаючими від неокорпоративістської моделі, Ф.Шміттер відносить Італію, США, Великобри- танію. Найближче до стабільної системи розподілу влади знаходяться Ірландія, Швейцарія, Голландія, Норвегія, Швеція. У цих країнах неокорпоративізм зберігає свої позиції як інструмент соціального миру, при цьому змістившись із національного рівня на мезо-(галузевий) і мікрорівні [13].

Висновки. Неокорпоративізм можна вважати майже ідеальною моделлю політичної системи, при якій панують комунітарно-етатистські цінності політичної поведінки. Вони визначають взаємодію держави і груп інтересів, які виступають головними інститутами самоорганізації громадянського суспільства.

Слід відзначити, що особливості сучасних суспільств у більшості країн світу припускають широке поле перспектив для подальших досліджень неокорпоративізму, в тому числі - його азіатської моделі, впливу глобалізації на роль і місце держави як такої, роль груп інтересів у демократизації суспільств, що трансформуються, аж до повного перегляду концептуальної моделі неокорпоративізму в умовах інформаційного суспільства. Процес соціально-політичних перетворень в українському суспільстві призвів до виникнення бюрократично-фінансової моделі корпоративізму, який, у певному сенсі, можна ототожнити з поняттям - олігархічний корпоративізм. Основні зусилля об'єднань вітчизняних підприємців спрямовані виключно на лобіювання інтересів бізнесу в органах виконавчої і законодавчої влади [3].

В останні роки сформувалася система залежності українського бізнесу від держави, що надає цій взаємодії особливий характер. Стан і якість системи взаємодії держави з групами інтересів багато в чому визначають як загальний характер української 
демократії, так і особливості державного управління, що на спадок має «родимі плями» централізованої радянсько-комуністичної системи. Їй притаманні такі риси, як державний патерналізм, знижена роль громадських спілок та об'єднань, які є не стільки самодіяльними асоціаціями, скільки «привідними ременями» державної політики у відповідних сферах життя суспільства. Крім того, доводиться мати справу з одержавленням асоціацій і об'єднань. Як приклад - доля українських профспілок, які практично позбулися своєї самостійної функції [5].

3 огляду на останні події політичної історії України можна припустити, що неокорпоративна модель представництва інтересів бізнесу та громадянського суспільства може забезпечити узгодженість, доцільність, усвідомлену скоординованість публічного управління з публічними поведінкою і діяльністю людей, сприяючи гармонізації суспільних відносин і тому щоб уникнути подальших політичних криз і масових протестних акцій. Звідси - не тільки наукове, а й практичне значення дослідження неокорпоративізму, висновки якого можуть виявитися корисними та актуальними при визначенні шляхів розвитку та вдосконалення системи представництва інтересів в Україні [12].

Надання діалогу «влада - групи інтересів» цивілізованого демократичного характеру та підвищення репрезентативності останніх - одна 3 неодмінних умов виходу 3 кризи та створення передумов формування правової держави. Сьогодні, поки що, йде пошук нової, більш гнучкої моделі взаємовідносин влади тільки з групами інтересів великого бізнесу, що $є$ потужною зацікавленою групою, але не єдиною. Країні необхідна державна політика спрямована на інституціалізацію корпоративного представництва всіх груп підприємців, на деполітизацію діалогу влади та бізнесу, а також на «рівновіддаленість» держави від бізнесу [7].

При цьому держава у будь-якому випадку буде змушена вирішити складне завдання - сфера економіки і приватного підприємництва повинна бути самостійна, але лише частково. Найбільш стратегічно важливі галузі економіки повинні бути під контролем держави (повернуті у державну власність), щоб не допустити повторного олігархічного зрощування власності і влади. В першу чергу це стосується енергетичної галузі української економіки.

Українській державі належить створити правову нішу для легітимного функціонування підприємницьких спілок та асоціацій з метою впливу на політику державних інститутів і визначити, з одного боку, допустимий оптимум цього коридору економічної свободи, а 3 іншого максимально вмонтувати механізми ринкового саморегулювання в структури реалізації функцій держави. В цьому і полягає основна мета конструктивної взаємодії владних і підприємницьких структур [11].

Вектори розвитку, інтенсивність i результати впливу глобалізації на національні держави теж залишаються предметом дискусії. Цілком очевидно, що у процесі формування світової політики і міжнародних відносин зростає роль неурядових акторів, а саме: транснаціональних корпорацій. В умовах світу глобальної взаємозалежності концепція неокорпоративізму набуває нового значення, враховуючи, до того ж, що історичні потрясіння і фундаментальні суспільні зміни минулого сторіччя не завадили розвитку неокорпоративізму як явища, притаманного ліберальним демократичним країнам. 
СПИСОК АІТЕРАТУРИ:

1. Васецкий А. А. Корпоративизм и политическая составляющая его развития // Управленческое консультирование. - 2007. - № 4 - 2007. - № 4. [Електронний ресурс]. Режим доступу: http://elibrary.ru/ contents.asp?issueid=641831 - 1997. - № 2 .

2. Гайнутдинов Р. И. Бизнес и политика в современном обществе. СПб., Изд-во РГПУ им.

А. И. Герцена, 2005.

3. Гончар В.М. Корпоративізм як модель взаємодії держави і громадянського суспільства: автореф. дис... канд. політичних наук: спец. 23.00.02 / В.М. Гончар. - Київ, 2009. - 24 с.

4. Зудин А. Ю. Ассоциации - Бизнес - Государство. «Классические» и современные формы отношений в странах Запада: Препринт WP1/2009/05. - М.: Изд. дом Государственного университета - Высшей школы экономики, 2009. - С. 8 - 16. [Електронний ресурс] // Препринты Государственного университета - Высшей школы экономики. - Режим доступу: http://new.hse.ru/C3/C18/preprintsID/default.aspx

5. Конструктивний діалог з владою УСПП. [Електронний ресурс] // Офіційний веб-сайт Української спілки промисловців і підприємців України. Режим доступу: http://www. uspp.org.ua/about/dialogue/

6. Королев Е. Модели взаимодействия бизнеса и власти в Европейском Союзе // Власть. 2008. - № 7.

7. Кудряченко А. Інститут соціального партнерства як чинник демократичного розвитку суспільства: світовий досвід та висновки для України. Аналітична записка. [Електронний peсурс] // Офіційний веб-сайт НІСД. Режим доступу: http://www.niss.gov.ua/ Monitor/ Juli08/19.htm2008

8. Салмин А.М. Неокорпоративизм в странах Запада // Полития. - 2005. - № 3 (38).

9. Пшизова С. Н. Бизнес как субъкт государственной политики // Управленческое консультирование. - 2009. - № 4. [Електронний ресурс]. Режим доступу: http://elibrary.ru

10. Тристоронні органи на національному рівні. Досвід європейських країн [Електронний ресурс] // Веб-сайт Національної тристоронньої соціально-економічної ради. Режим доступу: Національна тристороння соціально-економічна рада //http://www.ntser.gov.ua/ua/ dialog/ experience.html

11. Телешун С. О., Рейтерович I. В. Вплив фінансово-політичних груп на прийняття стратегічних рішень у сфері політики та економіки: українські реалії. - К.Х. - 2008.

12. Феномен неокорпоративізму: європейські реалії та тенденції інституціювання в Україні / І.С.Сало, О.О.Даниляк, Т.В.Джига / за заг. ред. В.М.Яблонського, С.О.Янішевського. К.: НІСД, 2010.

13. Шмиттер Ф. Неокорпоративизм и консолидация неодемократии. [Електронний ресурс]. Режим доступу : http://zhurnal.ru/polit/articles/cup2.html

14. Шмиттер Ф. Неокорпоративизм // Полис. 1997. №2. С. 14-22.

15. Schmitter P. Still in the Century of Corporatism? / Trends towards corporatist intermediation and policy making. Eds. Schmitter P, Lehmbruch G - Beverly Hills, CA: Sage, 1979.

\section{REFERENCES:}

1. Vasetskiy A. A. Korporativizm i politicheskaya sostavlyayuschaya ego razvitiya (Corporatism and political component of its development). Upravlencheskoe konsultirovanie. 2007. № 4, 2007. № 4. Mode of access: http://elibrary.ru/ contents.asp?issueid=641831 - 1997. - № 2 .

2. Gaynutdi №v R. I. Biznes i politika v sovremen№m obschestve (Business and politics in modern society). SPb., Izd-vo RGPU im. A. I. Gertsena, 2005.

3. Honchar V.M. Korporatyvizm yak model vzaiemodii derzhavy i hromadianskoho suspilstva (Corporatism as a model of cooperation between the state and civil society). Kyiv, 2009. $24 \mathrm{p}$.

4. Zudin A. Yu. Assotsiatsii - Biznes - Gosudarstvo. "Klassicheskie» i sovremennyie formyi otnosheniy v stranah Zapada: Preprint WP1/2009/05 (Association - Business - State. The "classical" and modern forms of relations in the West, Preprint WP1 / 2009/05). M.: Izd.dom Gosudarstvennogo universiteta - Vyisshey shkolyi eko №miki, 2009. P. 8-16. Mode of access: http:// new.hse.ru/C3/C18/preprintsID/default.aspx

5. Konstruktyvnyi dialoh z vladoiu USPP (Constructive dialogue with the authorities of UMB). Mode of access: http://www.uspp.org.ua/about/dialogue/

6. Korolev E. Modeli vzaimodeystviya biznesa i vlasti v Evropeyskom Soyuze (Models of interaction between business and government in the European Union). Vlast. 2008. № 7.

7. Kudriachenko A. Instytut sotsialnoho partnerstva yak chynnyk demokratychnoho rozvytku suspilstva: svitovyi dosvid ta vysnovky dlia Ukrainy. Analitychna zapyska (Institute of Social Partnership as part of a democratic development of society: international experience and les- 
sons for Ukraine. Policy Brief). Mode of access: http://www.niss.gov.ua/ Monitor/Juli08/19. htm2008

8. Salmin A.M. Neokorporativizm v stranah Zapada (Neo-corporatism in Western countries). Politiya. 2005. № 3 (38).

9. Pshizova S. N. Biznes kak sub'kt gosudarstvennoy politiki (Business as subkt public policy). Upravlencheskoe konsultirovanie. 2009. № 4. Mode of access: http://elibrary.ru

10. Trystoronni orhany na natsionalnomu rivni. Dosvid yevropeiskykh krain (Tripartite bodies at the national level. The experience of European countries). Mode of access: Natsionalna trystoronnia sotsialno-ekonomichna rada //http://www.ntser.gov.ua/ua/dialog/ experience.html 11. Teleshun S. O., Reiterovych $I$. V. Vplyv finansovo-politychnykh hrup na pryiniattia stratehichnykh rishen u sferi polityky ta ekonomiky: ukrainski realii (The impact of the financial and political groups in the strategic decision-making in politics and economy: the Ukrainian realities). K.Kh. 2008.

12. Fenomen neokorporatyvizmu: yevropeiski realii ta tendentsii instytutsiiuvannia v Ukraini (The phenomenon neokorporatyvizmu: European realities and trends instytutsiyuvannya in Ukraine). K.: NISD, 2010.

13. Shmitter F. Neokorporativizm i konsolidatsiya neodemokratii (Neo-corporatism and consolidation of neo-democracy). Mode of access : http://zhurnal.ru/polit/articles/cup2.html

14. Shmitter F. Neokorporativizm (Neo-corporatism). Polis. 1997. № 2. P. 14-22.

15. Schmitter P. Still in the Century of Corporatism?/ Trends towards corporatist intermediation and policy making. Eds. Schmitter P, Lehmbruch G - Beverly Hills, CA: Sage, 1979.

Квітка Сергій Андрійович - кандидат філософських наук, доцент

Дніпропетровський регіональний інститут державного управління Національної академії державного управління при Президентові України

Адреса: 49044, м. Дніпропетровськ, вул. Гоголя, 29

E-mail:skvitka@i.ua

Kvitka Serhii Andriiovych - PhD in philosophy, associate professor

Dnepropetrovsk regional institute of public administration, the National academy of public administration, office of the President of Ukraine

Address: 29, Gogol Str., Dnipropetrovsk, 49044

E-mail:skvitka@i.ua 